\title{
A Requirement for DNA Synthesis during Auxin Induction of Cell Enlargement in Tobacco Pith Tissue
}

\author{
By \\ MAHESHWARI, M. G. and L. D. NOODÉN \\ Department of Botany, University of Michigan, Ann Arbor, Michigan 48104 \\ (Received August 8, 1970)
}

\begin{abstract}
Abstraet
IAA (indoleacetic acid) is known to induce cell enlargement without cell division in tobacco pith explants grown on an agar medium without added cytokinin. The very long lag period before IAA $\left(2 \times 10^{-5} M\right)$ stimulates growth, about 3 days, can be useful to study the metabolic changes which lead to the promotion of growth. When the disks are transferred to a medium without IAA after 2 days or less of treatment with IAA, the IAA does not stimulate growth. Disks transferred after 3 days, subsequently show an auxin response, almost as great as those given IAA continuously. At $5 \times 10^{-4} M, 5$-fluorodeoxyuridine (FUDR), which inhibits DNA synthesis by blocking formation of thymidylate, completely suppresses the IAA-induced growth if it is added together with the IAA or 1 day later. When the FUDR is given 2 days after the IAA, there is a small increment of auxin-induced growth, and an even greater amount if added after 3 days. The period when exogenous auxin must be present to stimulate growth corresponds to the period of FUDR sensitivity. The FUDR inhibition is prevented by thymidine but not by uridine. Other inhibitors of DNA synthesis, hydroxyurea and fluorouracil, also inhibit auxin-induced growth. Thus DNA synthesis seems to be required for auxin induction of cell enlargement in tobacco pith explants. In contrast, FUDR does not inhibit auxin-induced growth in corn coleoptile and artichoke tuber sections.
\end{abstract}

\section{Introduction}

Nuclear DNA synthesis is known to occur in many nondividing, differentiating cells including enlarging cells $(7,9,15,30,33,34,35)$; however, the role of this DNA synthesis (endoreduplication) in development is not yet known. In tobacco pith explants, auxin induces both cell enlargement and an increase in nuclear DNA without cell division $(9,19,34)$. This study employs inhibitors of DNA synthesis to show that it is required for auxin induction of cell enlargement in tobacco pith disks. The DNA synthesis appears to be necessary for the induction of cell enlargement and not to sustain the growth once it starts.

\section{Materials and Methods}

Tobacco plants (Nicotiana tabacum cv. Wisconsin 38) were grown in the Matthaei Botanical Gardens at the University of Michigan. The plants were cut back to about $30 \mathrm{~cm}$ from the soil or to within $15 \mathrm{~cm}$ from the primary stem one or more times and the stems which grew from lateral buds were used. The stems were taken toward the end of their elongation phase but before the flowers opened.

Precautions were taken to obtain axenic pith sections, and all manipulations were performed in a sterile transfer chamber. Only the third through the sixth internodes from the tip were used in these experiments. This corresponds roughly to the region which responds geotropically. After the leaves were removed the stems were divided into smaller pieces about 6 to $8 \mathrm{~cm}$; the outer layers were peeled off from the stem sections; these segments were swabbed with $70 \%$ ethanol and plugs were obtained by boring through the stem with a cork borer (diameter about $0.7 \mathrm{~cm}$ ). All the disks which were measured at any one incubation time were taken from the same internodal region of a single stem. The plugs of pith were cut into $1 \mathrm{~mm}$-thick sections (average fresh weight $32 \mathrm{mg}$ ) and were distributed on petri plates containing Newcomb's basal medium (25), $2 \%$ sucrose, $0.7 \%$ agar with $2 \times 10^{-5} \mathrm{M}$ IAA (from a stock solution adjusted to $\mathrm{pH} 5.5$ with $\mathrm{NaOH}$ ) and other additives when specified. These were sterilized by autoclaving, but the 5-fluorodeoxyuridine (FUDR), 5-fluorouracil, hydroxyurea, actinomycin D, 8-azaguanine and colchicine (from $\mathrm{K}$ and $\mathrm{K}$ Laboratories, Inc.) were sterilized by filtration and added to the agar medium before it had solidified. Petri plates with the disks were incubated in 


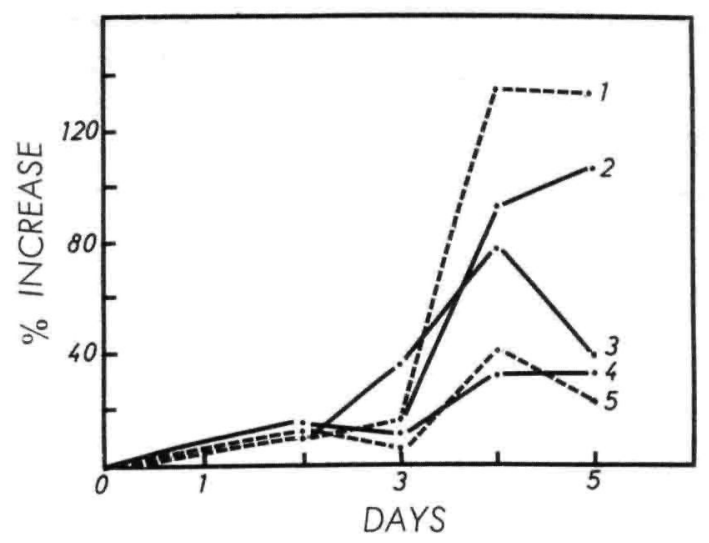

Figure 1. Auxin-induced growth in tobacco pith disks. Effect of FUDR added at various times after auxin. Curves: (1) IAA $\left(2 \times 10^{-5} M\right)$, (2) IAA + FUDR $\left(5 \times 10^{-4} M\right)$ at 3 days, (3) IAA + FUDR at 2 days, (4) IAA + FUDR, (5) $\mathrm{H}_{2} \mathrm{O}$. Ordinate: Increase in fresh weight.

the dark at $24^{\circ} \mathrm{C}$. In transfer experiments from IAA to water, the disks were cultured in medium with IAA and then at different time intervals were transferred to a medium with $\mathrm{H}_{2} \mathrm{O}$, sucrose and agar only. Care was taken to prevent the transfer of bits of agar with the disks. Growth was measured as the increase in the fresh weight of the tobacco pith. The disks were blotted gently to remove any surface water and weighed quickly.

The experiments with corn coleoptile sections and aged artichoke tuber disks were carried out as described earlier $(28,29)$.

\section{Results}

The auxin-induced growth responses observed here with tobacco pith disks are very similar to those reported by Newcomb (25) except that the percentage increase in fresh weight is somewhat larger in these experiments (Figure 1). The lag time before the auxin effect on growth becomes evident is about 3 days. After this lag the tissues grow rapidly for 2 to 3 days; then, for unknown reasons, the fresh weight often starts to decline. Not all of the cells in the disks respond equally to the auxin; almost all of the enlargement occurs in cells in the upper surface of the disks, and these cells become so large that they are easily visible to the unaided eye. Since there was some seasonal variation in the kinetics of the response to auxin, the time course studies shown here were all done from November through January.

At $5 \times 10^{-4} M$, FUDR, an inhibitor of DNA synthesis, added with IAA completely suppresses IAA-induced cell enlargement in tobacco pith explants, reducing it to the level of the water control (Figure 1).

Tobacco pith disks incubated in IAA for 2 days and then transferred to a medium with IAA and FUDR show a tendency to escape from the inhibitory effects of FUDR
Table 1. Effect of uridine and thymidine on FUDR inbibition of IAA-induced growth in tobacco pith explants.

\begin{tabular}{c|c}
\hline Treatment & $\begin{array}{c}\text { Increase in } \\
\text { fresh weight } \\
\text { after } 5 \text { days, \% } \%\end{array}$ \\
\hline
\end{tabular}

$\mathrm{H}_{2} \mathrm{O} \ldots \ldots \ldots \ldots \ldots \ldots \ldots \ldots \ldots \ldots \ldots$

IAA $\left(2 \times 10^{-5} M\right) \ldots \ldots \ldots \ldots \ldots \ldots$

IAA + thymidine $\left(10^{-3} M\right) \ldots \ldots \ldots \ldots$

IAA + uridine $\left(10^{-3} M\right) \ldots \ldots \ldots \ldots$.

IAA + FUDR $\left(5 \times 10^{-4} M\right) \ldots \ldots \ldots \ldots$

IAA + FUDR + thymidine $\ldots \ldots \ldots \ldots . \quad 102$

IAA + FUDR + uridine $\ldots \ldots \ldots \ldots \ldots . \quad 32$

(Figure 1). After 4 days of treatment with IAA (including 2 days of exposure to FUDR), these explants reach a fresh weight about halfway between the water controls and those treated with auxin alone. Pith explants which were allowed to grow in IAA for 3 days before treatment with FUDR are even less inhibited by the FUDR and the growth continues through the fifth day. Transfers made at 1 day (not given in Figure 1) show no tendency to escape from FUDR inhibition.

FUDR inhibition of IAA-induced growth is largely prevented by thymidine at $10^{-3} \mathrm{M}$. While thymidine raises the growth in presence of FUDR towards the IAA controls (Table 1), thymidine alone causes no promotion of IAA-induced growth. Uridine on the other hand does not alleviate the FUDR inhibition; in fact it even inhibits growth slightly.

Table 2 shows the effect of some other inhibitors of DNA synthesis on growth of the tobacco disks. Hydro-

Table 2. Inbibition of auxin-induced growth in tobacco pith explants by bydroxyurea, 5-fluorouracil, 8-azaguanine and actinomycin $D$.

Treatment

Increase in fresh weight after 5 days, $\%$

$\mathrm{H}_{2} \mathrm{O} \ldots \ldots \ldots \ldots \ldots \ldots \ldots \ldots \ldots \ldots$

IAA $\left(2 \times 10^{-5} M\right) \ldots \ldots \ldots \ldots \ldots$.

IAA + hydroxyurea $\left(10^{-3} \mathrm{M}\right) \ldots \ldots \ldots$

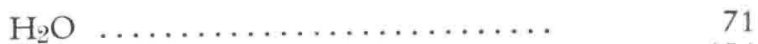

IAA $\ldots \ldots \ldots \ldots \ldots \ldots \ldots \ldots \ldots \ldots \ldots$

IAA +5 -fluorouracil $\left(5 \times 10^{-3} M\right) \ldots \quad 61$

$\mathrm{IAA}+\quad " \quad\left(10^{-3} M\right) \ldots \ldots .90$

$\mathrm{H}_{2} \mathrm{O} \ldots \ldots \ldots \ldots \ldots \ldots \ldots \ldots \ldots \ldots \ldots$

IAA $\ldots \ldots \ldots \ldots \ldots \ldots \ldots \ldots \ldots \ldots$

IAA + actinomycin D $(10 \mathrm{mg} / \mathrm{l}) \ldots \ldots \quad 45$

$\mathrm{IAA}+\quad, \quad(1 \mathrm{mg} / \mathrm{l}) \ldots \ldots . \quad 76$

$\mathrm{IAA}+\quad " \quad(0.1 \mathrm{mg} / \mathrm{l}) \ldots \ldots$

$\mathrm{H}_{2} \mathrm{O} \ldots \ldots \ldots \ldots \ldots \ldots \ldots \ldots \ldots \ldots \ldots \ldots$

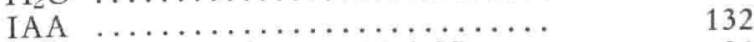

IAA + 8-azaguanine $\left(7 \times 10^{-4} \mathrm{M}\right) \ldots . \quad 36$

$\mathrm{IAA}+, \quad\left(3 \times 10^{-4} \mathrm{M}\right) \ldots \ldots \quad 46$

$\mathrm{IAA}+\quad, \quad\left(10^{-4} \mathrm{M}\right) \ldots \ldots \ldots$.

$\mathrm{IAA}+\quad " \quad\left(10^{-5} M\right) \ldots \ldots$. 
Table 3. Lack of inhibition by FUDR of IAA-induced growth in corn coleoptile sections and aged artichoke tuber disks.

Increase in fresh weight, $\%$

Treatment

\begin{tabular}{c|c}
\hline $\begin{array}{c}\text { Corn coleoptile } \\
\text { sections }\end{array}$ & Aged artichoke disks
\end{tabular}

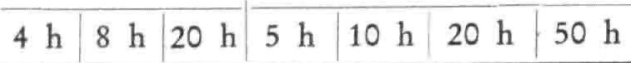

\begin{tabular}{|c|c|c|c|c|c|c|c|}
\hline $\mathrm{H}_{2} \mathrm{O}$ & 4 & 11 & 32 & 3.3 & 4.8 & 5.3 & 5.9 \\
\hline FŨDR $\left(10^{-3} \quad M\right)$ & 5 & 13 & 35 & - & - & - & \\
\hline IAA $(10 \mathrm{mg} / \mathrm{l}) \ldots$ & 19 & 41 & 91 & 2.4 & 5.6 & 11.1 & \\
\hline IAA + FUDR & 17 & 37 & 87 & 2.3 & 5.3 & 12.0 & \\
\hline
\end{tabular}

xyurea at $10^{-3} M$ produces a $45 \%$ reduction in the IAAinduced response. 5-Fluorouracil at $5 \times 10^{-3} M$ prevents the IAA-induced growth completely, but $10^{-3} M$ suppresses this growth by $78 \%$. Thus fluorouracil is considerably less effective than FUDR where $5 \times 10^{-4} \mathrm{M}$ or less can suppress auxin-induced growth completely.

Actinomycin D, an inhibitor of DNA-dependent RNA synthesis, inhibits auxin-induced cell enlargement in tobacco pith tissue just as it does in a wide variety of other tissues $(22,28,29)$. In this tissue unlike most others, actinomycin D is able to produce complete inhibition of the auxin-induced growth and this occurs at only $10 \mathrm{mg} / \mathrm{l}$, a relatively low concentration (Table 2 ). Even $0.1 \mathrm{mg} / 1$ produces a $40 \%$ inhibition of the growth induced by IAA. 8-Azaguanine, an analog of the nucleic acid base guanine $(21,22,28,29)$, also inhibits the auxin-induced growth of the disks with inhibition decreasing from $100 \%$ at $3 \times 10^{-4} \mathrm{M}$ to $27 \%$ at $10^{-5} \mathrm{M}$.

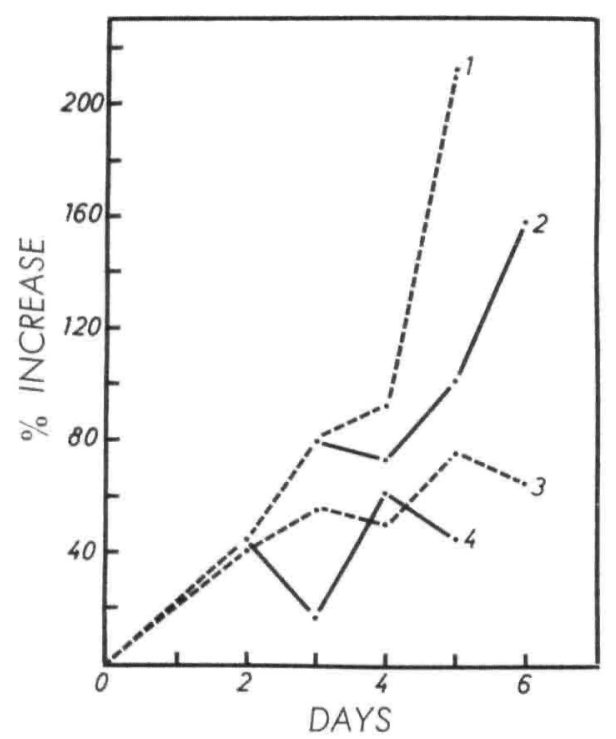

Figure 2. Auxin-induced growth in tobacco pith disks. Effect of removal of the exogenous auxin supply at various times. Curves: (1) IAA, (2) IAA to $\mathrm{H}_{2} \mathrm{O}$ at 3 days, (3) $\mathrm{H}_{2} \mathrm{O}$, (4) IAA to $\mathrm{H}_{2} \mathrm{O}$ at 2 days. IAA $2 \times 10^{-5} \mathrm{M}$. Ordinate: Increase in fresh weight.
Tobacco pith tissue is more sensitive to actinomycin and azaguanine than most plant tissues (see 22, 28, 29).

Colchicine, an inhibitor of cell division (11), does not affect the auxin induction of growth when applied at $0.2 \%$, a concentration which is much higher than those used to inhibit cell division in other plant tissues (11, 15 ); however, $1 \%$ does inhibit growth completely. One $\%$ colchicine also completely suppresses auxin-induced corn coleoptile growth (change in fresh weight, measured over a shorter period, 20 hours).

Our results with tobacco pith are contrasted with corn coleoptile sections and aged artichoke tissue (Table 3 ). FUDR at $10^{-3} M$ shows no effect on the IAA-induced growth response in the latter two tissues. Similarly hydroxyurea, even at $0.05 \mathrm{M}$, did not inhibit the growth of the corn coleoptile sections. The lack of FUDR inhibition of IAA-induced cell enlargement in these and other tissues (4, p. 465 in 22) suggests that there may be something unusual about the auxin-induction of cell expansion in tobacco pith disks.

Tobacco pith disks incubated in IAA for 2 days and then transferred to a medium without IAA normally fail to show any IAA-induced growth response (Figure 2). In one experiment, however, these disks started to grow after 5 days, a lag phase of more than 5 days. If the pith sections are allowed to incubate in IAA for 3 days and then transferred to water, growth of the transferred explants continues till 6 days.

\section{Discussion}

This study aims to determine whether or not DNA synthesis is a prerequisite for auxin-induced cell enlargement in tobacco pith explants. Earlier studies using the DNA synthesis inhibitor FUDR on a variety of tissues indicate that usually auxin-induced cell enlargement and often cell enlargement in tissues which may not be regulated by auxin do not require DNA synthesis $(4,13$, $22,28)$. Furthermore, fluorouracil, which also blocks DNA synthesis, does not affect cell expansion in many tissues (see 22). Similarly, cell expansion occurs in seedlings from seeds given massive doses of $\gamma$ radiation -(doses reported to suppress DNA but not RNA synthesis), and although these "gamma plantlets" never reach the size of normal plants (due to suppression of cell division), their constituent cells reach the normal or even greater size (16).

Our experiments demonstrate that FUDR inhibits the auxin-induced cell enlargement in tobacco pith disks. FUDR is well known as a selective inhibitor of DNA synthesis in plants and other organisms; its action depends upon causing thymidylic acid deficiency by blocking thymidylate synthetase $(5,27)$. The specificity of FUDR action on the tobacco pith explants is substantiated by the prevention of FUDR effect with thymidine and not uridine, nevertheless its effect on DNA synthesis 
may lead to an inhibition of RNA synthesis $(5,13,37)$ and even synthesis of some enzymes $(13,32)$.

This requirement for DNA synthesis adds special interest to the earlier work of Silberger and Skoog (34), who showed that auxin induces an increase in DNA content along with growth in tobacco pith. It should be noted, however, that they observed the promotion of DNA accumulation could be generated by concentrations of IAA too low to effect growth, thus the stimulation of DNA synthesis does not necessarily result in growth.

The next question is does the observed requirement for DNA synthesis continue throughout the lag and cell enlargement period or is there an escape from this requirement? Our data based on addition of the FUDR at various times after the IAA show that there is at least a partial escape from FUDR inhibition after 2 days and even more after 3 days. FUDR added even one day after the IAA still produces complete inhibition of growth. Thus it appears that the required DNA synthesis may not even have started during the first day and may be completed by 3 days. Since the incubation times used were very long, it is unlikely that slowness in penetration is responsible for the failure of FUDR to produce a complete suppression of auxin-induced growth when added 2 or more days after the auxin. Furthermore, the fact that the tobacco pith disks are strongly inhibited by a concentration of actinomycin $\mathrm{D}(0.1 \mathrm{mg} / \mathrm{l})$ which has relatively little effect on most other tissues (see 22, $28,29)$, indicates that there is no unusual barrier to penetration since even actinomycin $\mathrm{D}$, a relatively large molecule (molecular weight 1255), enters the disks readily.

Silberger and Skoog (34) reported that auxin had started to increase the DNA per disk by the end of the second day of treatment and this increase reached a maximum by the fourth day. Because their lag phase was longer than ours, their results can not be directly extrapolated to ours. In their experiments the auxin-induced increase in DNA was completed about the time when disks showed a growth response. Likewise in our experiments, the sensitivity of growth to FUDR was almost completely gone about the time the growth response had started.

Other inhibitors of DNA synthesis, namely hydroxyurea (23) and fluorouracil $(5,21,22)$, also bear out the necessity for DNA synthesis in auxin-induced growth of tobacco pith.

In addition it was found that the auxin did not have to be present in the incubation medium continuously. The escape from this requirement occurred around 3 days. Thus this tissue does not require a continuous external supply of auxin to maintain growth; instead, the exogenous auxin needed only for the induction process. A similar escape from the requirement for exogenous auxin has been noted earlier in aged artichoke tubers (28). Some other hormonal responses, for example the effect of aldosterone on the short-circuit current in toad bladders (10) do not require continuous presentation of the hormone; however, some others do $(8,12)$.

As mentioned above auxin-induced cell enlargement in many plant tissues does not require DNA synthesis. In oat coleoptiles (4), soybean and pea stems $(13,17)$, corn coleoptiles and aged artichoke tuber disks (Table 3), FUDR does not inhibit the auxin-promoted growth. This difference in the FUDR sensitivity of the different tissues may reflect an important difference in the metabolic requirements for growth; however, it is possible that even coleoptiles require some special DNA synthesis to set the stage for cell expansion, but this could occur much earlier, long before the elongation phase begins. Artichoke tuber disks provide an example; here FUDR inhibits auxin-induced growth when added before (20) but not after the aging period (Table 3 ). Interestingly, the nuclei of artichoke tuber disks do not increase significantly in DNA content during the aging period (1). Furthermore, even in oat coleoptiles where some cells undergo postmitotic DNA synthesis, the cells which have a 2C DNA content apparently grow as well as those with more (33). Thus it appears that even where DNA synthesis is required, the necessary portion may be relatively small, and the massive postmitotic DNA synthesis in enlarging cells may not be required for the expansion.

Nitsan and Lang $(26,27)$ and Bopp and BoppHassenkamp $(3,4)$ have shown that FUDR can reduce gibberellic acid-induced cell enlargement in lentil epicotyls and stems of Kalanchoe daigremontiana plantlets respectively. Atsmon and Dagani (2) have also reported that FUDR suppresses both gibberellin- and auxininduced elongation in cucumber hypocotyls. At least in the case of lentil epicotyls, it was later noted that cell division may be a prerequisite for the gibberellin-induced cell enlargement (see p. 465 in 22). Indeed, cell division (and/or DNA synthesis) is also necessary for gibberellin but not cytokinin promotion of cell enlargement in leaf disks (see p. 401 in 18). It is, nonetheless, of interest that these cells must pass through mitosis (and probably at least one round of DNA synthesis) in order to be programmed for expansion in response to GA. This phenomenon, a requirement for cell division or DNA synthesis in order to be reprogrammed, may also be important in developmental processes other than cell expansion, for example induction of floral apex development (36) and wound xylem differentiation (15).

We believe that mitosis does not contribute to the growth of the tobacco tissue used in this study. In the first place, Jablonski and Skoog (19) have reported that no detectable cell division occurs under these conditions (even if minerals and vitamins are included in the medium). Secondly, while it is true that colchicine, an inhibitor of mitosis, does affect the auxin-induced cell enlargement in tobacco explants, it does so only at con- 
centrations much higher than those which normally inhibit cell division in plant tissues $(11,15)$, thus this inhibition is possibly due to an impurity in the colchicine or some other type of action by colchicine such as inhibition of nucleic acid synthesis (14). This suggestion is strongly supported by our observation that the same concentration of colchicine $(1 \%)$ also produces complete inhibition of IAA-induced growth (increase in fresh weight) in corn coleoptile sections.

The observation that DNA synthesis is required for auxin-induction of cell enlargement in tobacco pith disks raises questions about why DNA synthesis should be required anyhow in nondividing cells. Perhaps certain genes must be multiplied to give many copies in order to provide an adequate amount of template for RNA synthesis or needed mitochondrial synthesis is blocked through an effect on mitochondrial DNA replication by the inhibitors or certain genes may be expressed (or derepressed) only during the period when they are being replicated. The genes which would be amplified according to the first possibility could even be ribosomal genes $(7,31)$ since cell expansion in tobacco pith explants has been shown to be correlated with a large increase in cellular RNA which is most likely ribosomal RNA (34). Although auxin produces a large stimulatory effect on respiration in the pith tisue even before it affects growth (25), the second explanation cited seems the least likely. At least in artichoke tuber disks, it is possible to inhibit the auxin-induced increase in $\mathrm{O}_{2}$ uptake without reducing growth (28); however, this may not apply to the tobacco pith. The third possibility is given some support by the observation that the nitrite metabolizing enzymes in Chlorella are most effectively induced by nitrite during the period of DNA synthesis (24).

In any case postmitotic DNA synthesis or endoreduplication has been observed in many differentiating cells and it would be of interest to learn which aspects of cell differentiation require this DNA synthesis and why this dependency exists.

We gratefully acknowledge partial support from a National Science Foundation Research Grant during the early stages of this study and from a Public Health Service Grant from the Institute of Environmental Health Sciences during the later phases.

We are also indebted to Hoffman-LaRoche, Inc. for a generous supply of 5-fluorodeoxyuridine and 5-fluorouracil and to Mr. Don Trout of the Matthaei Botanical Gardens for providing a steady supply of tobacco stems.

\section{References}

1. Adamson, D.: Expansion and division in auxin-treated plant cells. - Can. J. Bot. 40: 719-744. 1962.

2. Atsmon, D. \& Dagani, Y.: Auxin- and gibberellininduced elongation in cucumber hypocotyl as related to DNA synthesis. - Proc. XI Internatl. Bot. Congr., Seattle, Wash. 1969.
3. Bopp, M.: Internodienstreckung bei dikotylen Pflanzen und DNA-synthese. - Exp. Cell Res. 48: 218-221. 1967.

4. - \& Bopp-Hassenkamp, G.: Beeinflussung der Zellstrekkung durch 5-FUDR. - Naturwiss. 24: 664. 1965.

5. Brockman, R. W. \& Anderson, E. P.: Biochemistry of cancer (Metabolic aspects). - Ann. Rev. Biochem. 32: 463-512. 1963.

6. Broughton, W. J.: Relations between DNA, RNA and protein synthesis and the cellular basis of the growth response in gibberellic acid-treated pea internodes. Ann. Bot. 33: 227-243. 1969.

7. Brown, D. D. \& Dawid, I. B.: Specific gene amplification in oocytes. - Science 160: 272-280. 1968.

8. Chrispeels, M. J. \& Varner, J. E.: Hormonal control of enzyme synthesis: on the mode of action of gibberellic acid and abscisin in aleurone layers of barley. Plant Phystol. 42: 1008-1016. 1967.

9. Das, N. K., Patau, K. \& Skoog, F.: Autoradiographic and microspectrophotometric studies of DNA synthesis in excised tobacco pith tissue. - Chromosoma 9:606-617. 1958.

10. Edelman, I. S., Bogoroch, R. \& Porter, G. A.: On the mechanism of action of aldosterone on sodium transport: the role of protein synthesis. - Proc. Natl. Acad. Sci. U.S. 50: 1169-1177. 1963.

11. Eigsti, O. J. \& Dustin, P. Jr.: Colchicine in Agriculture, Medicine, Biology and Chemistry. - Iowa State College Press, Ames, Iowa. 1955.

12. Evans, M. L. \& Hokanson, R.: Timing of the response of coleoptiles to the application and withdrawal of various auxins. - Planta 85: 85-95. 1969.

13. Fan, D. \& Maclachlan, G. A.: Massive synthesis of ribonucleic acid and cellulase in the pea epicotyl in response to indoleacetic acid, with and without concurrent cell division. - Plant Physiol. 42:1114 1122. 1967.

14. Fitzgerald, P. H. \& Brehaut, L. A.: Depression of DNA synthesis and mitotic index by colchicine in human lymphocytes. - Exp. Cell Res. 59:27-31. 1970.

15. Fosket, D. E.: Cell division and differentiation of woundvessel members in cultured stem segments of Coleus. - Proc. Natl. Acad. Sci. U.S. 59: 1089-1096. 1968.

16. Haber, A. H., Carrier, W. L. \& Foard, D. E.: Metabolic studies of gamma-irradiated wheat growing without cell division. - Am. J. Bot. 48:431-438. 1961.

17. Holm, R. E. \& Key, J. L.: Hormonal regulation of cell elongation in the hypocotyl of rootless soybean: an evaluation of the role of DNA synthesis. - Plant Physiol. 44: 1295-1302. 1969.

18. Humphries, E. C. \& Wheeler, A. W.: The physiology of leaf growth. - Ann. Rev. Plant Physiol. 14:385-410. 1963.

19. Jablonski, J. R. \& Skoog, F.: Cell enlargement and cell division in excised tobacco pith tissue. - Physiol. Plant. 7: 16-24. 1954.

20. Kamisaka, S. \& Masuda, Y.: Auxin-induced growth of Helianthus ruber tissue. V. Role of DNA synthesis in hormonal control of cell growth. - Ibid. 23:343-350. 1970.

21. Key, J. L.: Effect of purine and pyrimidine analogues on growth and RNA metabolism in soybean hypocotyl - the selective action of 5-fluorouracil. Plant Physiol. 41: 1257-1264. 1966.

22. Key, J. L.: Hormones and nucleic acid metabolism. Ann. Rev. Plant Physiol. 20: 449-474. 1969.

23. Kihlman, B. A., Eriksson, T. \& Odmark, G.: Effects of hydroxyurea on chromosomes, cell division and nucleic acid synthesis in Vicia faba. - Hereditas 55: 386-397. 1966. 
24. Knutsen, G.: Induction of nitrite reductase in synchronized cultures of Chlorella pyrenoidosa. - Biochim. Biophys. Acta 103: 495-502. 1965.

25. Newcomb, E. H.: Dissociation of the effects of auxin on metabolism and growth of cultured tobacco pith. Physiol. Plant. 13: 459-467. 1960.

26. Nitsan, J. \& Lang, A.: Inhibition of cell division and cell elongation in higher plants by inhibitors of DNA synthesis. - Devel. Biol. 12: 358-376. 1965.

27. - - DNA synthesis in the elongating nondividing cells of the lentil epicotyl and its promotion by gibberellin. - Plant Physiol. 41: 965-970. 1966.

28. Noodén, L. D.: Studies on the role of RNA synthesis in auxin induction of cell enlargement. - Ibid. 43:140150. 1968.

29. - \& Thimann, K. V.: The action of inhibitors of RNA and protein synthesis on cell enlargement. - Ibid. 41: 157-164. 1966.

30. Partanen, C. R.: On the chromosomal basis for cellular differentiation. - Am. J. Bot. 52: 204-209. 1965.
31. Pelc, S. R.: Turnover of DNA and function. - Nature (London) 219:162-163. 1968.

32. Seitz, K. \& Lang, A.: Invertase activity and cell growth in lentil epicotyls. - Plant Physiol. 43:1075-1082. 1968.

33. Setterfield, G.: Structure and composition of plant-cell organelles in relation to growth and development. Can. J. Bot. 39: 469-489. 1961.

34. Silberger, J., Jr. \& Skoog, F.: Changes induced by indoleacetic acid in nucleic acid contents and growth of tobacco pith tissue. - Science 118:443-444. 1953.

35. Stange, L.: Plant cell differentiation. - Ann. Rev. Plant Physiol. 16: 119-140. 1965.

36. Zeevaart, J. A. D.: Physiology of flowering. - Science 137: 723-731. 1962.

37. Zotin, A. I., Milman, L. S. \& Faustov, V. S.: ATP level and cleavage of sea urchin eggs Strongylocentrotus dröbachiensis (O. F. Müller). - Exp. Cell Res. 39: 567-576. 1965. 
This document is a scanned copy of a printed document. No warranty is given about the accuracy of the copy. Users should refer to the original published version of the material. 